\title{
Phytochemical screening and antibacterial activity of neem extracts on uropathogens
}

\author{
Aziz Fatima ${ }^{1}$, Taqdees Malik ${ }^{*}$, Ifrah Ibrahim ${ }^{2}$ and Sayyada Ghufrana \\ Nadeem ${ }^{1}$ \\ 1. Department of Microbiology, Jinnah University for Women, Karachi-74600-Pakistan \\ 2. Medical Mycology Research and Reference Laboratory-Pakistan \\ *Corresponding author's email: taqdees_13@ hotmail.com \\ Citation \\ Aziz Fatima, Taqdees Malik, Ifrah Ibrahim and Sayyada Ghufrana Nadeem. Phytochemical screening and \\ antibacterial activity of neem extracts on uropathogens. Pure and Applied Biology. Vol. 9, Issue 1, pp148-153. \\ http://dx.doi.org/10.19045/bspab.2020.90018
}

Received: $15 / 05 / 2019 \quad$ Revised: 28/08/2019

Accepted: 28/09/2019

Online First: 03/10/2019

\section{Abstract}

The study investigates the antibacterial activity of leaves ethanolic extract of Azadirachta indica on human uro-pathogens that having the ability to cause urinary tract infections. The extract screened for S. aureus, E.coli and P. aeruginosa, for their antimicrobial efficiency. For this purpose, MIC, MBC and antibiotic sensitivity test were performed. Zones were appeared in agar well-containing leaf extract as compared to sensitivity test. The difference between MIC and MBC at tube 4 neem show the activity against $E$. coli and $P$. aeruginosa while for $S$. aureus results showed the inhibitory effect. The phytochemical analysis shows that neem has components which enhance the antimicrobial activity of neem. Phytochemical screening of neem not only having antimicrobial activity but also have antifungal, antiviral properties this activity of neem comes due to its bitter taste and the taste is due to the presence of components likes alkaloids, flavonoids, triterpenes. In current era the antibiotics therapies are more risky to cure infection because antibiotics has vast side effects that directly effects the certain body parts mainly kidney, stomach, upper and lower respiratory tract not only effects but also cause respective body organs disorder So, to subside the effects of antibiotics we are now able to cure microbial infections by the use of herbal medicine. In which NEEM has played a vital role to cure both infections skin as well as inner body infections.

Keywords: Azadirachta indica; MIC; MBC; Phytochemical analysis; antimicrobial activity

Introduction

The emergence of multidrug-resistant organisms in the present era is becoming a big issue [1]. This concept is changing now because of the use of the non-toxic medicinal plant. In order to manufacture effective drugs which can be able to treat such types of infections which can be initiated by the multi- drug resistant organisms [1]. The versatile medicinal plant is neem (Azadirachta indica) which have several chemical and biological properties which are effective against infections.as we know very well that the UTI urinary tract infection is a second most common infection of both males and females approx. 8.1 million peoples carry this 
infection with or without symptoms each year (Lane and Thakkar). UTI is more common in females as compared to males. The most common cause is hospital-acquired UTI which is approximately $40 \%$ the age of women is a very important factor, 2-7 \% cases reported in their fertility period, more high rate of cases reported at the age 40-50 that is $50 \%$.and $7-10 \%$ case reported in males at the age of 70-75. The infection is carried out when bacteria start to colonize in the bladder and weaken the urinary system [2]. The number of bacteria may be $10,0000 / \mathrm{ml}$ to cause infection. The most common pathogens are gram-negative including E.coli, Pseudomonas, Klebsiella, Proteus, Serratia, and gram-positive bacteria Staph. aureus [3]. 90\% of cases are caused by gramnegative organisms and $10 \%$ of cases reported by gram-positive bacteria $[4,5]$. The severity of infection start when the pathogens build resistivity against antibiotics by developing certain changes it may include the changing of the target site of drugs, destroying the antibiotics. This changes will help to makes the infections more severe and more fatal. [6] By using medicinal plant we can be able to treat the infection because it contains certain structure which helps to recover the infection. Neem is one of the oldest plants which can use as folk medicine. Neem is an evergreen tree cultivated worldwide; it was used as a therapeutic agent for certain infections. In the past era neem used to treat tooth decay and skin problems but nowadays neem also used to treat many infections including hair problems, ulcer, tumors, diabetes, abdominal pain, fever, cough, etc. Neem not only having properties to treat infections but also have anti-oxidant, anti-malarial, anti-carcinogenic, antimutagenic, and anti-inflammatory and antihyperglycemic properties [7]. In the modern era, many pharmaceutical companies are engaged in discovering drugs by using medicinal plants like Neem. It is a versatile plant which shows antibacterial and antifungal properties as well as antiviral activity viruses like vaccinia, chikungunya, measles and coxsackie virus [8]. The plant leaves not having antimicrobial properties but its bark, seeds, flower, fruit, and roots also having these properties [9]. Neem is well known for their antibacterial property because it contains certain compounds which make the neem antimicrobial and due to these compounds neem's taste is bitter which real power against harmful microbes is. The powerful active components are alkaloids, flavonoids, glycosides, triterpenes, reducing sugars, tannins, saponins, and anthraquinones. This study aimed to investigate the antibacterial against uropathogens and phytochemical screening of neem ethanolic extracts [10]. Neem not only helps to prevent the infections but also used in place of antibiotics. Antibiotics are very well known to cure the infections but also involved to destroy the immune system. When antibiotics kill the bacteria our immune system also damaged to avoid this type of damage we use medicinal plants to cure disease with damaging the immune system [11].

\section{Materials and methods Collection of isolates}

The clinical urine isolates were used in this research, were collected from the Department of Microbiology lab of Jinnah University for Women and also from the City Lab and Diagnostic Center. The isolates were then purified and stored. Total 3 bacterial strains were used. Two were gram-negative E.coli and Pseudomonas and remaining 1 was gram-positive $S$. aureus.

\section{Preparation of plant extract}

The neem extract was made in two different ways in ethanol and in distilled water to check the antibacterial activity.

\section{Neem extract in methanol}

Fresh leaves of Neem were collected locally and were air dried in shade. Before obtaining 
the extract first make the powder of leaves by grounding the leaves using a grinder and make a fine powder. Take $2 \mathrm{gm}$ of neem leaves powder and add in $20 \mathrm{ml}$ of ethanol mix well in $100 \mathrm{ml}$ of the flask. Put the flask on a mechanical shaker for two days. After two days filter, this suspension by the help of watt's man filters paper 1 into another flask. Preserved the extract in brown bottle place the bottle in the refrigerator.

\section{Neem extract in distilled water}

Take $2 \mathrm{gm}$ of neem leaves powder and add in $20 \mathrm{ml}$ of distilled water mix well in $100 \mathrm{ml}$ of the flask. Put the flask on a mechanical shaker for one week. After one week filter, this suspension by the help of watt's man filters paper 1 into another flask. Preserved the extract in brown bottle place the bottle in the refrigerator.

\section{Agar well diffusion method}

In $1 \mathrm{ml}$ sterile saline add 4-5 colonies of respective cultures till the moderate turbidity was developed and then match with McFarland tube 0.5. The fresh inoculum was ready to use. Take sterile swab and dip the swab into the inoculum before removing the swab touch the swab to the wall of the tube so that the excess inoculum removed. Make lawn on the MHA plates. After owning make two vials by the help of borer one for aqueous extract of neem which served as control and second for ethanolic extract of neem. Now add $30 \mu \mathrm{l}$ of both extracts into the vials. Incubate these plates at $37^{\circ} \mathrm{Cfor} 24$ to 48 hours for the examination of zones.

\section{Minimum inhibitory concentration method}

For MIC take 9 tubes of $10 \mathrm{ml}$ for each organism (E. coli, Pseudomonas, and Staph) having $1 \mathrm{ml}$ MHA broth. Label the tubes as $0.25,0.5,1,2,4,8,16,32$ and control. From 1 $\mathrm{ml}$ discard respective microliters to maintain the volume except for the control. Now add $0.25,0.5,1,2,4,8,16,32 \mu \mathrm{l}$ of neem ethanolic extract by the help of jester and $1 \mathrm{ml}$ fresh culture in all 9 tubes so the control contains $1 \mathrm{ml}$ broth and $1 \mathrm{ml}$ culture. Properly cover the tubes and incubate the tubes at $37^{\circ} \mathrm{C}$ for $24-48$ hours to check the non-turbid tubes.

\section{Minimum bactericidal concentration method}

Take MHA agar plates according to the nonturbid tubes. From the non-turbid tubes take $0.1 \mathrm{ml}$ and streak on plates. Incubate the plates at $37 \mathrm{C}$ for 24 hours. Next day count the CFU/ml (30-300 colonies) to check the bactericidal activity of neem.

\section{Antibiotics sensitivity test}

Take three MHA plates and make lawn by using fresh cultures of (E. coli, Pseudomonas, and Staph). Place synthetic antibiotics discs of penicillin, Cephalosporin, Ampicillin, and Novobiocin on the MHA plates. Incubate the plates at $37 \mathrm{C}$ for 24 hours. Next day observed the zones.

\section{Phytochemical analysis of neem leaves}

To check the phytochemical analysis of neem leaves used different reagents. The compounds of neem are alkaloids, glycoside, flavonoid, triterpenes, tannins, and saponins.

\section{Alkaloids}

The test also called as Meyer's test. The extract of neem evaporated till dryness and the residue was heated with $2 \% \mathrm{HCl}$ in a boiling water bath. After cooling and filtration add few drops of MEYER's reagent in the mixture. The turbidity or yellow precipitation shows the presence of alkaloids components.

\section{Glycoside}

To the extract add Glacial acetic acid, few drops of Ferric chloride and Concentrated Sulphuric acid. Reddish brown coloration at the junction of two layers and the bluish green color in the upper layer observed.

\section{Flavonoids}

$4 \mathrm{mg}$ of extract solution treated with $1.5 \mathrm{ml}$ of $50 \%$ methanol solution. In warmed solution add metal magnesium, and 5-6 drops of concentrated hydrochloric acid red color were observed for flavonoids. 


\section{Triterpenes}

The extract mixed with $5 \mathrm{ml}$ of chloroform, warmed at $80^{\circ} \mathrm{C}$ for 30 minutes. Add a few drops of concentrated sulphuric acid, mixed well red color formation appeared

\section{Tannins}

$0.5 \mathrm{ml}$ of extract solution add $1 \mathrm{ml}$ of water, 1-2 drops of ferric chloride solution. The bluish green color appears for tannins.

\section{Saponins}

In $2 \mathrm{~g}$ powered sample of neem leaves were boiled a water bath containing $20 \mathrm{ml}$ distilled water and filtered.10 $\mathrm{ml}$ filtered solution mixed with $5 \mathrm{ml}$ of distilled water then add 23 drops of olive oil, shake well and observed for emulsion formation.

\section{Results}

The study was done to check and interpret the antibacterial activity of neem leaves to extract on human uro-pathogens like $E$. coli, Pseudomonas, and $S$. aureus by different methods including Agar well diffusion, antibiotic discs sensitivity test, Minimum inhibitory concentration, minimum bactericidal concentration. The ethanolic extract of neem show the zones of inhibition against Pseudomonas that is $23 \mathrm{~mm}$, E. coli that is $25 \mathrm{~mm}$, and for $S$. aureus is $26 \mathrm{~mm}$ as shown in (Table 1). The result interprets that the maximum zone of inhibition of ethanolic extract of neem was found against $S$. aureus. The result of agar well diffusion compared with synthetic antibiotic disc diffusion against the same bacteria that cause urinary tract infection, the antibiotics used were cephalosporin, penicillin, ampicillin, and novobiocin. Presence of zones indicates that the neem extract has antibacterial activity. This activity is due to the presence of chemical and biological constituents like Alkaloids, Glycosides, Triterpenes, Saponins, Tannins, and flavonoids which can be determined by performing phytochemical screening of neem leaves which are mentioned below in (Table 2). Constituents like Tannins, Glycoside, Alkaloid, Saponins were found positive in the neem extract while Flavonoid and Triterpenes were found negative which indicates that Tannins, Glycoside, Alkaloid, Saponins have strong antibacterial activity. As per the Macrobroth dilution method performed, the results revealed that the neem extract inhibits the growth E. coli and Pseudomonas strains with the concentration $8 \mathrm{ug} / \mathrm{ml}, 16 \mathrm{ug} / \mathrm{ml}, 32 \mathrm{ug} / \mathrm{ml}$ whereas the growth of $S$. aureus was inhibited 4, 8, 16, 32 but the MBC showed the colonies on MHA plates means having inhibitory effects not killing effect.

Table 1. Antibacterial activity of $A$. indica showing zones of inhibition by Agar well diffusion

\begin{tabular}{|c|c|c|}
\hline Name of organism & Zone of inhibition & Control \\
\hline Pseudomonas & $23 \mathrm{~mm}$ & no zone \\
\hline E.coli & $25 \mathrm{~mm}$ & no zone \\
\hline Staph.aureus & $26 \mathrm{~mm}$ & no zone \\
\hline
\end{tabular}

Table 2. Phytochemical screening of Neem leaves

\begin{tabular}{|c|c|c|}
\hline Test & Color appear & Result \\
\hline Tannins & Green black color appears & $+\mathrm{ve}$ \\
\hline Glycoside & The red ring appears at the bottom and green appear at the top & $+\mathrm{ve}$ \\
\hline Flavonoid & No red color appears & $-\mathrm{ve}$ \\
\hline Alkaloid & Turbidity observed & $+\mathrm{ve}$ \\
\hline Saponins & Emulsion formation appear & $+\mathrm{ve}$ \\
\hline Triterpenes & No color appears & $-\mathrm{ve}$ \\
\hline
\end{tabular}




\section{Minimum inhibitory concentrations (MIC) of neem extract}

The minimum inhibitory concentration (MIC) of ethanol extracts of neem showed the highest inhibition for L. monocytogenes $(0.1 \mathrm{mg} / \mathrm{mL}), \quad S$. aureus (strain 01) (0.1 $\mathrm{mg} / \mathrm{mL}), S$. aureus (strain 02) $(0.1 \mathrm{mg} / \mathrm{mL})$, and $V$. parahaemolyticus $(0.1 \mathrm{mg} / \mathrm{mL})$ and the lowest inhibition for Alcaligenesfaecalis, Aeromonashydrophila $(4.0 \mathrm{mg} / \mathrm{mL})$, and $A$. hydrophila $(4.0 \mathrm{mg} / \mathrm{mL})$. The MIC of chloroform extracts of neem showed similar inhibition for L. monocytogenes $(4.0 \mathrm{mg} / \mathrm{mL})$ and L. monocytogenes $(5.0 \mathrm{mg} / \mathrm{mL})$. However, ethanol extracts of neem showed higher inhibition for $S$. aureus (strain 01) (4.5 $\mathrm{mg} / \mathrm{mL}$ ) and $S$. aureus (strain 02) (4.5 $\mathrm{mg} / \mathrm{mL}$ ) and the lower inhibition for other microorganisms $(6.5 \mathrm{mg} / \mathrm{mL})$. No significant effects of temperature and $\mathrm{pH}$ were found on neem extracts against cocktails of $L$. monocytogenes and $S$. aureus. The results of the present study suggest that neem extracts possess compounds containing antibacterial properties that can potentially be useful to control foodborne pathogens and spoilage organisms

\section{Discussion}

Many synthetic drugs can cause various side effects. Hence, the development of plants based compound to the demand for the production of newer drugs with no or minimal side effects. Neem (A. indica) possess a good antibacterial activity with great potential of bioactive compounds useful for health care. In this study, the ethanolic extract of neem leaf exhibit high antibacterial activity against all tested bacterial strain i.e. S.aureus, E.coli, and Pseudomonas. The results were similar to the studies performed by Mohammed et al. [12]. In agar well diffusion the zones appear within the range of $23 \mathrm{~mm}$ zones against Pseudomonas, $25 \mathrm{~mm}$ against E.coli and $26 \mathrm{~mm}$ against S.aureus and which indicates that the S.aureus is more sensitive to neem. The results were also compared to synthetic antibiotics. According to Awasthyand his colleague reported that the neem is very useful to treat oral infections. [13] The aqueous extract of neem did not show the antibacterial activity against any of the isolates. These findings were correlated with the study done by Bhargava et al, Rajsekharan and Agarwal et al. [14, 15]. The neem extract inhibit the $E$. coli and Pseudomonas strains in the tube 8, 16, 32 tubes while $S$. aureus inhibits in the tube $4,8,16,32$ but the MBC showed the colonies on MHA plates means having inhibitory effects not killing effect. The antimicrobial potential of neem is due to its constituents, the phytochemicals compounds of neem such as alkaloids, glycosides, flavonoid, tannins, saponins Nostro. In the present study, found that the ethanolic extract of neem having these biologically active compounds like alkaloids, glycosides, tannins, flavonoids, triterpenes, saponins the antibacterial activity of neem extract may due to the presence of above-mentioned components [10].

\section{Conclusion}

Azadirachta indica (neem) extract has antibacterial activity against UTI pathogens.it is mainly due to the phytochemical compounds like alkaloids, glycosides, flavonoids, tannins, triterpenes, saponins. From this study, it may be concluded that the neem has an inhibitory effect not cidal effect against both grampositive and gram-negative organisms that caused UTI. In the future, the infections can be treat by using medicinal plant (neem) rather than the synthetic antibiotics which have side effects as well as these are more resistant to pathogens. So, we can be able to produce drugs which not only treat infections but also have no more side effects.

\section{Authors' contributions}

Conceived and designed the experiments: A Fatima \& I Ibrahim, Performed the experiments: A Fatima \& I Ibrahim, Analyzed the data: A Fatima \& I Ibrahim, 
Contributed materials/ analysis/ tools: A Fatima, T Malik, I Ibrahim \& SG Nadeem, Wrote the paper: A Fatima \& T Malik.

\section{Reference}

1. Jain D, Jayaram L, Prabhu VM \& Bhat GK (2013). Antibacterial effect of neem (Azadirachta indica) oil on multidrugresistant bacteria isolated from human infections. Inter $J$ of Biol \& Med Res 4(4): 3544-3546.

2. Jepson RG \& Craig JC (2007). A systematic review of the evidence for cranberries and blueberries in UTI prevention. Mol Nutr \& Food Res 51(6): 738-745.

3. Sharma A, Verma $\mathrm{R}$ \& Ramteke $\mathrm{P}$ (2009). Antibacterial activity of some medicinal plants used by tribals against UTI causing pathogens. World Appl Sci $J$ 7(3): 332-33.

4. Chacón-Mora N, Díaz JP \& Matía EC (2017). Urinary tract infection in kidney transplant recipients. Enfermedades Infecciosasy Microbiol Clin 35(4): 255259.

5. Flores-Mireles AL, Walker JN, Caparon M \& Hultgren SJ (2015). Urinary tract infections: epidemiology, mechanisms of infection and treatment options. Nature Rev Microbiol 13(5): 269.

6. Micheal A \& Kochanski DD (2010). How antibiotics kill bacteria: from targets to networks. 423-435.

7. Vasantharaj S, Sathiyavimal S \& Hemashenpagam N (2013). Phytochemical analysis and antibacterial activity of Azadirachta indica. Inter J of
Pharmaceutical Sci Rev and Res 22: 5961.

8. Parida MM, Upadhyay C, Pandya G \& Jana AM (2002). Inhibitory potential of neem (Azadirachta indica Juss) leaves on dengue virus type-2 replication. $J$ Ethnopharmacol 79(2): 273-278.

9. Alzohairy MA (2016). Therapeutics role of Azadirachta indica (Neem) and their active constituents in diseases prevention and treatment. EvidenceBased Complementary and Alternative Medicine 7382506.

10. Faiza Aslam KRM (2009). Department of Biochemistry, University of Agriculture Antibacterial Activity of Various Phytoconstituents of Neem 46(3): 209-213.

11. Hancock RE \& Speert DP (2000). Antibiotic resistance in Pseudomonas aeruginosa: mechanisms and impact on treatment. Drug Resistance Updates 3(4): 247-255.

12. Hala AM \& Al Fadhil AO (2015). Antibacterial Activity of Azadirachtaindica(Neem) Leaf Extract against Bacterial Pathogens in Sudan. American J of Res Comm 3(5): 246-251.

13. Awasthy K (1999). Phytotherapy research, prolonged murine genotoxic effects of crude extract from neem, pp 81-83.

14. Bhargava KA (1981), Indian Journal of medical microbiology, Antibacterial properties of tulsi. Indian $J$ of Med Microbiol 443-451.

15. Agarwal P (1996) Medicinal herb tulsi. Inter J Clin, Pharmacol 406-409. 